\section{PROF. H. MARSHALL WARD, F.R.S.}

$\mathrm{I}^{\mathrm{T}}$ is long since the cause of British botany has sustained so severe a loss as that from which it is now suffering by the deaths, within a few days of each other, of Charles Baron Clarke and of Harry Marshall Ward. Though differing widely in most respects, in age, in pursuits, in circumstances, yet this they had in common, high distinction in their respective lines of work and a long record of devoted and unremitting toil. It is not for me to attempt an appreciation of Clarke--that will be done by more competent hands-but I cannot forbear this slight tribute of esteem and regard. Nor is it possible for me, within the limits of space and time at my disposal, to give an at all adequate account of Ward's life and work. I can only aim at recalling some of the memories of a personal association at one time most intimate, at no time entirely severed, and at merely indicating the scope and the value of his achievements.

My acquaintance with Ward dates from the year 1875. In the spring of that year I was assisting Sir William. Thiselton-Dyer at the Royal College of Science, South Kensington, in the conduct of a course of instruction in botany, one of the earliest courses of practical study, in the modern sense, ever given in this country. We were both struck by the singular intelligence and enthusiasm of one of our pupils, who, we felt, ought to be secured for the service of botany. That pupil was Ward. At our suggestion he became a candidate, in the spring of 1876 , for an open scholarship in natural science at Christ's College, Cambridge, where I was a lecturer, and, having obtained the scholarship, he came into residence in October of that year. His undergraduate career was marked by a further development of those characteristics that had so impressed Sir William ThiseltonDyer and myself at South Kensington. Under considerable difficulties, the practical teaching of botany was being established in the University; but whatever the shortcomings of the instruction, they were amply compensated by the earnestness of the students, who, besides Ward, included Prof. Bower, F.R.S., of Glasgow; Dr. Hill, Master of Downing College; Prof. Hillhouse, of Birmingham; Dr. Walter Gardiner, F.R.S., and others. However, Ward did not confine himself to the study of botany, but availed himself to the full of the excellent opportunities for acquiring a sound knowledge of physiology under Sir Michael Foster, and of comparative anatomy under the late Prof. F. M. Balfour. A first-class in the natural sciences tripos of 1879 was a fitting close to his undergraduate days at Cambridge.

After taking his degree Ward went abroad for purposes of study, and worked for some time under the late Prof. Sachs at Würzburg; but the respite from botanical duty was not long. In 1880 he was called upon, as cryptogamic botanist to the Government of Ceylon, to go out and investigate the coffeeleaf disease then ravaging the island, a difficult task that he accomplished with considerable success. On his return, in 1882 , he was elected Berkeley fellow at Owens College, Manchester, and became assistant to the late Prof. Williamson, F.R.S. Here he laboured for three years, and did much to promote the growth of the botanical school, leaving Manchester in $188_{5}$ to become professor of botany in the forestry department of the Royal Indian Engineering College, Coopers Hill. In the meantime (188, ) he had been elected a fellow of his old college at Cambridge. For ten years he remained at Coopers Hill, throwing himself with his habitual energy into the life of the place, until in 1895 he succeeded the late Prof. NO. I 924 , VOL. 74$]$
C. C. Babington, F.R.S., as professor of botany in the University of Cambridge, becoming at the same time professorial fellow of Sidney Sussex Collige. In this larger and most congenial sphere he found full scope for the play of his activities in every dircction. Supported by a highly competent staff, and with such colleagues as Mr. F. Darwin, F.R.S., reader in botany, Dr. Gardiner, F.R.S., and Mr. Seward, F.R.S., university lecturers, Ward soon succeeded, by his infectious enthusiasm, in giving a fresh impulse to the progress of his science at Cambridge. He himself always took charge of the large elementary class, and won therefrom many recruits for the ranks of botany by the attractiveness of his lectures; he gave besides one or more courses on advanced subjects during the year, generally, as might be expected, on some groups of fungi. His weak point as a teacher is eminently characteristicit was that he generally attempted to cover a great deal more ground, to convey a great deal more information in his lectures, than was possible either physically or mentally. He educated many who have since done excellent botanical work, for he not only taught his pupils what was known, but also inspired them to attack the unknown. Under him the botanical school attained such importance that the University allotted a large portion of the benefaction fund to the erection of a new botanical institute, one of the best in the country, which, together with other university buildings, was formally opened by $\mathrm{His}$ Majesty the King in March, I904.

So far I have spoken of Ward only as student and as teacher; I have yet to speak of him as investigator, his most important rôle. The bent towards original research was strong within him from the very first. His earliest papers date back to r879 (Journ. Linn. Soc., vol. xvii.; Quart. Journ. Micr. Sci., vol. xx.), and relate to the embryo-sac, a subject that, owing to the brilliant discoveries of Prof. Strasburger and others, was at the time especially engaging the attention of botanists; but it was not until his visit to Ceylon that he entered upon what was to be his life-work, the investigation of the fungi and bacteria. The first fruits of his work there was a series of three elaborate reports on the coffee-leaf disease to the Colonial Secretary (1880-I), and a scientific paper on the fungus producing it (Hemeleia vastatrix), read before the Linnean Society on June I, I882 (Journ., vol. xix.); moreover, his experience in this case led him to form views on the physiology of parasitism that influenced all his subsequent work. However, when in Ceylon his attention was not so wholly absorbed by the coffee disease as to prevent him from making other observations, the results of which are embodied in a paper on the perithecium of Meliola, published in the Phil. Trans. of the Royal Society, $188_{3}$, and in another on a curious epiphyllous Lichen, Strigula complanata, that appeared in the Trans. Linn. Soc., vol. ii., r884. After these, and two other papers on the Saprolegnia and on Pythium in the Quart. Journ. Micr. Sci., vol. xxiii., I883. there was for a time, owing to his transfer to Coopers Hill, a lull in the activity of publication, broken by the appearance in 1887 of two papers in the Phil. Trans., the one on Entyloma Ranunculi, the other on the tubercular swellings on the roots of Vicia Faba, of which the latter is of special interest. At this time the causation of these swellings and their relation to the nitrogenous nutrition of the plants bearing them was one of the leading problems of plant physiology. To the solution of this problem Ward's paper contributed the important facts that (I) the tubercles are undoubtedly of parasitic origin, and (2) that the parasite gains 
admission by the root-hairs, though he thought the parasite was a myceloid fungus, whereas it has since been proved to be a bacterium. The whole subject was admirably resumed by him in an article contained in vol. i. of the Annals of Botany (1887-8), of which periodical he was one of the founders. The same volume opens with a paper by him and Mr. T. Dunlop on the histology and physiology of the fruits and seeds of Rhamnus, perhaps one of the best of his researches, in which it is shown that the yellow pigment (rhamnin), obtained from the fruits for dyeing purposes, is formed by the decomposition of the glucoside (xanthorhamnin) contained in the pericarp by a ferment existing principally in the testa of the seed. In the second volume of the Annals (1888-9) there is an elaborate paper, "A Lily-disease," the chief point of interest being the discovery that the fungus (Botrytis) penetrates the cell-walls of the host by means of a ferment (since termed cytase) secreted at the tips of the hyphæ. Ward's views on parasitism were further developed in his paper "On some Relations between Host and Parasite in certain Epidemic Diseases of Plants" (Proc. Roy. Soc., vol. xlvii., I89o), which gained the honour of selection as the Croonian Lecture for that year. Passing over with mere mention the papers on Craterostigma (Trans. Linn. Soc., I89o) and on the Ginger-beer Plant (Phil. Trans., r892), I come to his most laborious achievement, a series of reports on the bacteriology of the Thames, presented, in conjunction with Prof. Percy Frankland, F.R.S., to the Water Research Committee of the Royal Society in the years $1893-6$. It is difficult to form any adequate conception of the unfailing assiduity necessary to the working out, as Ward did, of the life-histories of the no less than eighty different bacterial organisms that he found in the river, nor is it possible here to give an account of these voluminous documents, a résumé of which, so far as his share of the work is concerned, was given by him in the fifth report (Proc. Roy. Soc., vol. lxi., r897). He had proved his fitness for this difficult task by his paper "On the Characters or Marks employed for Classifying the Schizomycetes " in the Annals of Botany, vol. vi., r892, and the accomplishing of it gave rise to such interesting parerga as the papers "On the Action of Light on Bacteria "(Phil. Trans., 1895), "A Violet Bacillus from the Thames," and "Some Thames Bacteria " (Ann. Bot., xii., I898). The first of these papers is of considerable importance in that the bactericidal effect of light, whether of the sun or of the electric arc, is conclusively demonstrated, and is shown to be confined to the more highly refrangible rays of the spectrum.

Ward was a regular attendant at the meetings of the British Association for the Advancement of Science, and was president of the botanical section at the meeting in Toronto in 1897 . His address on that occasion dealt with a subject that was always in his mind, the economic significance of the fungi, of which he gave a characteristically exhaustive account. In fact, all his subsequent work was the expression of this idea. 'Thus in IS98 (Phil. Trans.) he published an investigation of Stereum hirsutum, the fungus that attacks the wood of the oak, having succeeded, by means of pure cultures, in tracing its life-history from the spore to the fructification, and he did the same for Onygena equina, the horn-destroying fungus (Phil. Trans., r899). He then entered upon what was destined to be his last line of research, the investigation of the Uredines or Rusts, with an energy that was remarkable even for him; but it was not until 1902 that the publication of the results began, so long and so numerous were the experiments from which they were drawn. The first paper on the sub- ject was read before the Cambridge Philosophical Society in January, I902 (Proc., vol. xi.), treating of the physiological races of these fungi, with special reference to the Brown Rust of the Brome-grasses. Having shown that certain species of Bromes can only be attacked successfully by certain forms or breeds of the Rust, he arrived at the striking conclusion that " the capacity for infection, or for resistance to infection, is independent of the anatomical structure of the leaf (of the Grass), and must depend upon some other internal factor or factors in the plant." Two papers published later on in the year (Proc. Roy. Soc., vols. Ixix. and 1xxi.) discuss the question, with an answer in the negative, as to whether or not susceptibility to infection depends upon the nutritive conditions offered by the host to the parasite, the foregoing conclusion being reasserted thus:- "All the evidence points to the existence, in the cells of the fungus, of enzymes or toxins, or both, and in the cells of the host-plant of antitoxins or similar substances, as the decisive factors in infection or immunity, although I have as yet failed to isolate any such bodies." In the meantime yet another paper had appeared in the Annals of Botany (vol, xvi., June, I902) confirming his previously expressed conviction that differences in details of anatomical structure do not afford any explanation of the relations between the Bromes and their Rusts. His last paper on this subject is that dealing with the adaptive parasitism of the Brown Rust (Annales Mycologici, vol. i., 1903), in which he developed the interesting idea of the existence of what he termed "bridging species." The idea is briefly this, that although it is generally true that the adapted races of the parasitic fungus are restricted to groups of closely allied host-species, there do occur host-species which serve as intermediaries in the passage of the parasite from members of one section of the hostgenus to those of another section.

Incidentally, a controversy arose between Ward and Prof. Eriksson, of Stockholm, with reference to the "mycoplasm-theory" of the latter. In order to account for the occurrence of sudden and widespread epidemics of Rust, Eriksson had assumed the persistence in a dormant state, within the tissues of the host-plants, of a combination of the protoplasm of the fungal hyphæ with that of the host, which he had described and figured and had called " mycoplasm." As stated in his paper on the question (Histology of Uredo dispersa, \&c., Phil. Trans., Ser. B, vol. cxcvi., 1903), Ward was unable to confirm Eriksson's observations, and regarded his assumption as unnecessary. One of the most interesting discussions in Section K during the Cambridge meeting of the British Association, 1904, was that in which the pros and cons of this theory were urged by the two protagonists. Their views were subsequently published, side by side, in the Annals of Botany (vol. xix., January, I905).

At this point the record of his work as an investigator abruptly ends, when great things might still have been anticipated, and it might well be deemed sufficient to have occupied all the time and energy at his disposal. However, this is far from being the case. Besides writing all these papers, many of them illustrated by elaborate drawings-for Ward was an excellent draughtsman-as well as others necessarily omitted here, he produced several books :- a translation of Sachs's "Physiology of Plants," I 884 ; "Timber and some of its Diseases," I 880 ; "The Oak," I892; an edition of Laslett's "Timber and Timber-trees," I894; "Diseases of Plants," 1889; "Grasses," I901; "Disease in Plants," I90I; "Trees," a considerable work, of

NO. 924 , VOL. 74] 
which several parts have appeared, and I understand that some MSS, remain to be published.

It is pleasant to reflect that so much good work was not allowed to pass unrecognised. In addition to the distinctions already mentioned, many others were conferred upon him. Ward became a Fellow of the Linnean Society in I886, and was elected a Fellow of the Royal Society in $\mathrm{x} 888$, receiving a Royal medal in 1893; he served on the council of the Linnean Society, I887-9, and on that of the Royal Society, I895-6. He was elected an honorary fellow of Christ's College, Cambridge, in 1897, and in 1902 received the degree of D.Sc. honoris causa from his first Alma Mater, the Victoria University, having previously taken the same degree at Cambridge. $\mathrm{He}$ was president of the British Mycological Society, I900-2, and had received the honorary fellowship of the Manchester Literary and Philosophical Society and of other societies.

Beginning in 1854 at Hereford, his life is a story of unremitting and successful effort until its close at Torquay on Sunday, August 26, rgo6. I remember Ward as a genial companion, a man of varied interests, delighting especially in music; but the dominant impression is that of his whole-hearted devotion to his science; all else counted with him as nothing in comparison with that. No doubt this led him to impose too severe a strain upon a constitution never very robust: but such as he was, it could not have been otherwise. He was laid to rest in the Huntingdon Road Cemetery, Cambridge, on September 3, attended by many friends and colleagues, amid tokens of regret from near and far.

S. H. VINES.

\section{CHARLES BARON CLARKE, F.R.S.}

THE death of Mr. Charles Baron Clarke on August 25, in his seventy-fourth year, deprives the botanical world of an able worker, and takes from a wider circle still a friend endeared for his breadth of sympathy and charm of manner.

Born at Andover in 1832, Clarke was educated at King's College School, London, and at Trinity and Queens' Colleges, Cambridge. He graduated in 1856 being bracketed third wrangler. Elected a fellow of Queens' in 1857 , he was in 1858 called to the Bar at Lincoln's Inn, and appointed mathematical lecturer of his college. This position he held until $186_{5}$, when he joined the Bengal Educational Department.

While at Cambridge Clarke was one of a brilliant group holding advanced economic views, which included Henry Fawcett, Leslie Stephen, and John Rigby. His interest in political economy continued throughout his life, and found expression in occasional pamphlets on economic subjects, which he treated in a manner pleasing for its lucidity and freedom from political bias.

Before he left England, Clarlze, as a recreation, was interested in field botany. On reaching India he printed at Calcutta, in I866, a list of the plants of Andover, his birthplace. Clarke began his Indian career as a teacher in the Presidency College, Calcutta, but soon became an inspector of schools. His work as inspector involved touring within the circle allotted to him, and gave him facilities for botanical field work. Of these he made the utmost use, and supplemented them by vacation visits to districts outside his circle and provinces beyond Bengal. He made extensive collections, and at the same time found material for contributions to ethnology and geography. From 5869 until I87I Clarke was in charge of the Royal Botanic Garden at Calcutta, with the use of a well-equipped herbarium at his command. The administrative work of these two years left little time for publication of results, but, on reverting to his own department, Clarke, while as ardent a collector as ever, found time to commence the issue of his valuable contributions to Eastern botany. His monographs of the Indian Cyrtandraceæ and Commelynaceæ were issued in 1874 ; that of the Indian Compositæ appeared in 1876. In the former year also, Clarke, at his own risk and cost, issued a new and cheap edition of Roxburgh's "Flora Indica," which had become almost unprocurable.

The extent and value of the field work done by Clarke during the first ten years of his Indian service may be best measured by the character of the collection presented by him to Kew in 1877 . This included 25,000 numbers, representing some 5000 species. The fulness of the notes, often accompanied by useful analyses; the precise indication of localities and altitudes; the excellence of the specimens themselves, combine to render this contribution one of the most munificent additions ever made to the Indian material at Kew. It represents journeys in the Bengal plain, on the Chutia Nagpur plateau, in Chittagong, in the Khasia Hills, in Sikkim from the Terai to the snows, in the Punjab Himalaya, in Kashmir and thence to the Karakoram, in the Nilgiri Hills. No botanist since Griffith had seen more of India; none since Hooker had more fully examined the areas visited.

Early in 1879 Clarke was placed on special duty in England, and for four years was engaged at Kew assisting Sir Joseph Hooker in the preparation of the "Flora of British India "; for the second, third, and fourth volumes of this work he prepared the accounts of many important natural families. While in England Clarke also published, in 1880 , a review of the "Ferns of Northe.n India." He returned to India early in 1883 , and towards the close of 1884 he was appointed to act as Director of Public Instruction, Bengal. In 1885 his services were transferred from Bengal to Assam, a change of province which admitted of his further exploration of the Surma and Brahmaputra valleys and of the Khasia and Jaintia Hills, and enabled him to make a botanical journey in the Naga Hills and Manipur, new ground even for him, the results of which were published in the Journal of the Linnean Society.

In 1887 Clarke retired from the Indian Service and settled at Kew, so as to be near the herbarium there, in which he worked for nineteen years as a volunteer. Early in his Indian career he appears to have been particularly attracted to the study of the Cyperaceæ, and one of the objects of his life was the completion of a general monograph of this difficult family, with regard to which Clarke became the recognised authority to whom botanists in every country sent their collections for identification and description. His devotion to this group, accounts of which he prepared for the "Flora of British India," the "Flora Capensis," and the "Flora of Tropical Africa," was not, however, exclusive, for he elaborated several important families for both the African "Floras" and for the "Flora of the Malay Peninsula," and communicated numerous botanical papers to the I.innean and Royal Societies.

Clarke joined the Linnean Society in I867, when his active botanical work in India first began. In the society's fortunes he took the keenest interest, being, while on special duty in England and again since his retirement, one of the most trusted councillors of the society, over which he presided from I894 until I896. He was elected a Fellow of the Royal Society in $\mathbf{I} 882$, and served on the council in I888-9. He was also a Fellow of the Geological and of the Geographical Societies.

No. I 924 , vOL. 74] 